\title{
Saving Souls or Saving Money: A Bargain of Conversion in G. B. Shaw's Major Barbara
}

\author{
Azeez Jasim Mohammed ${ }^{1}$ \\ ${ }^{1}$ Department of English, Faculty of Arts, Banaras Hindu University, Varanasi, India \\ Correspondence: Azeez Jasim Mohammed, Department of English, Faculty of Arts, Banaras Hindu University \\ (BHU), Varanasi 221005, U.P., India. Tel: 91-896-044-4737. E-mail: azizjasim73@yahoo.com
}

Received: August 30, 2012 Accepted: September 29, 2012 Online Published: October 16, 2012

doi:10.5539/ells.v2n4p53 URL: http://dx.doi.org/10.5539/ells.v2n4p53

\begin{abstract}
George Bernard Shaw, as a secular writer, in Major Barbara tries to bring about an ethical balance between power and morals. As a matter of fact, life is governed by power factors while morals are masks those taken off in case of emergency. The paper, however, examines the struggle between fanaticism and secularism and the misconception of the exact meaning of bribery and charity.

The conflict is based on a bargain between Barbara as a Major in the Salvation Army and Undershaft as ammunitions magnate. The challenge builds on a bet between the two competitors. Either Barbara saves the soul of a capitalist tradesman or the Major accepts saving money. The bargain takes two rounds. The fatal blow is dealt when the Army commissioner accepts, so to speak, 'tainted' money.

The paper gives a lesson to the in charges not to behave foolishly. They should realistically think to avoid harming a third party. On one hand, Major Barbara rejects the monetary support that is given to the Salvation Army to keep on its reputation while the commissioner, Mrs. Baines, accepts the money to keep on its shelters open. Who is bribed and who is loyal? On the other hand, Undershaft, a secular realist, believes in doing everything to avoid poverty but Barbara, a fanatic idealist, does everything she can to avoid a real disrepute. Who is right and who is wrong?
\end{abstract}

Keywords: realism, idealism, salvation, ammunitions, convert, charity, bribery, corruption

\section{Introduction}

“... People may differ about matters of opinion, or even about religion; but how can they differ about right and wrong? Right is right; and wrong is wrong; and if a man cannot distinguish them properly, he is either a fool or a rascal: that's all" (Shaw, 1965a, p. 463).

Much of the early literature of the modern period consists of sermons, prayers, lives of saints, and homilies. Somewhat later than the religious writers, the secular writers appear (Lombardi, 2012, para. 3). George Bernard Shaw, as a secular writer, in Major Barbara tries to bring about an ethical balance between power and morals. As a matter of fact, life is governed by power factors while morals are masks those taken off in case of emergency. Terry Teachout (2010) reported that "... anyone who knows anything about him [Shaw] will realize that "Major Barbara" hints, however unconsciously, at his own tendency to worship at the altar of power" (Teachout, 2010, para. 6). Shaw successfully achieves this concept in his play that makes it perpetual. I disagree with Nicholas Williams who says:

"In general, one can say that a play that deals with issues of its time has a very short life span. This is one of the greatest problems for a playwright like Bernard Shaw. In two of his most significant plays, Major Barbara (1905) and Pygmalion (1912), the issues examined seem to be essentially Edwardian; what then is there of intrinsic interest for today's audiences" (Williams, 2006, p. 143)?

In fact, Shaw is not a playwright of a specific era. His plays act as a bridge between the past and the present and successfully performed. Joel G. Fink (2011) impugns Williams’ polemic by saying:

"At a time when many theatre companies are struggling to fill seats, American Players Theatre (APT) consistently attracts large, engaged, loyal audiences to provocative, sometimes unknown plays. In programming ...Shaw's Major Barbara ... as part of its 2010 season, APT provided an unusual opportunity for 
its artists and audiences to be challenged by ... plays written by authors whose lives overlapped, but whose aesthetics and artistic goals did not (Fink, 2011, p. 272).

In Major Barbara, there are two conflicting parts. Shaw seems to be unaligned and thus criticizes both of the two rivals. The paper, however, examines the struggle between fanaticism and secularism and the misconception of exact meaning of bribery and charity. Charity is bribery when it aims at corruption. The point is; when and where the word corruption gets its meaning. The confusing understanding of corruption takes a wider space of this struggle. As I think, corruption is a way of accepting money for personal interests. In a case when a responsible person accepts donations for the public interests, it can hardly be considered as bribery and corruption!

In the play, the main argument is about a monetary support given to the Salvation Army ${ }^{1}$. The major conflict is with regard to the provenance of that money. Shaw in his preface to the play reported:

"On the point that the Army ought not to take such money, its justification is obvious. It must take the money because it cannot exist without money, and there is no other money to be had. Practically all the spare money in the country consists of a mass of rent, interest, and profit, every penny of which is bound up with crime, drink, prostitution, disease, and all the evil fruits of poverty, as inextricably as with enterprise, wealth, commercial probity, and national prosperity" (Shaw, 1965b, 124).

On the one hand, the two chief members of the Army have two different explanations regarding the donation. One of them assumes that; it is a way of destroying a religious establishment which aims at supporting the poor and displaced people and it may lead to disrepute. The other one seems to agree with Shaw's opinion in his preface to Major Barbara that they "would take money from the devil himself sooner than abandon the work of Salvation" (Shaw, 1965b, p. 131). They would "be only too glad to get it out of his hands and into God's" (Shaw, 1965b, p. 124). This disparity and disagreement between the two members of the Salvation Army paves the way to a third party to interpenetrate and weaken it. The more insistence of the rivals is on the shoulders of the Salvation Army and the poor people themselves. On the other hand, a bargain of convert between Major Barbara and her father Andrew Undershaft is interwoven. The bargain refers to the struggle between two camps; the capitalists as seculars and the socialists as fanatics. Thus, the bargain reveals the hidden disputation and points to a cold war between the two conflicting parts. Let me hasten to say, one part of the army accepts the monetary support and holds the argument in support of the purity of the money. Whether charity or bribery, the argument helps to split the Salvation Army and disillusion its members.

In the early period of establishing the Salvation Army, savers of souls and money worked compatibly. Their aims were to make the Army famous and successful. 'William Booth preached to the poor, and Catherine Booth, the "Mother of the Salvation Army", spoke to the wealthy, gaining financial support for their work'(Wiki). Shaw's criticism of the Salvation Army is the hypocrisy of lamenting over money provenance and the disparity of principles among the members. The lack of understanding and harmony creates a gap between the savers of souls. The unsatisfactory food provided by the Army and complains of the saved persons also pave the way for the rivals to transfuse. Price, a saved person of the West Hamm shelter, claims the meal is not enough. At the beginning, Barbara is aware of this problem and seeks a way of gaining the support and hence laments over the poverty of the Army. When Bill ${ }^{2}$ returns from his excursion defeated, Jenny ${ }^{3}$ expresses her sympathy. Bill refuses her forgiveness and offers to pay her to square off their debt. Barbara, sharply, forbids Jenny to take his money for the Army.

\section{The Craftsmanship of Contraries}

Shaw's plays represent the conflict between two contraries. In Major Barbara, Shaw's contraries are idealism and realism, poverty and plutocracy, religion and capitalism and fanaticism and secularism. The craftsmanship of contraries is typically acquired from William Blake. Blake approached the two contraries in his poem The Marriage of Heaven and Hell. Shaw in his foreword to Irving Fiske's Bernard Shaw's Debt to William Blake stated:

"Blake was a tiptop pioneer, and not mere freak or sport, is provided by the fact that I should have written much as I did if Blake had never been born. Robert Owen, Sam Butler, Oscar Wilde, Nietzsche and others were unconsciously Blakist without, as far as I know, having ever read The Marriage of Heaven and Hell" (Fiske, 1974, p. 1).

Shaw's technique in his play is the open ended playwrighting. He creates two contraries, brings them altogether then sets them in. This conflict enables him to work at his satire and irony. He finally leaves solutions to the reader to decide. Shaw completely believes 'without contraries is no progression. Attraction and repulsion, reason and energy, love and hate, are necessary to human existence' (qtd. in Morgan, 1972, p. 134). 
It is time to introduce the two rivals. Barbara Undershaft ${ }^{4}$ is a Major in the Salvation Army. Andrew Undershaft ${ }^{5}$ is munitions and cannons tradesman. The character of Undershaft is an example of Shaw's realism, capitalism and secularism. He intends to support the Salvation Army with the money they need after a request from the Army commissioner. Barbara is Shaw's representative figure of idealism, socialism and fanaticism. She calls Undershaft's money as 'tainted' and when accepting it the establishment would turn corrupt. The character of Mrs. Baines ${ }^{6}$, the Commissioner in the Salvation Army, is an example of Shaw's clement and reasonable person. She represents a mixture of Barbara and Undershaft. She maintains quite distinctly that saving money is a right way for continuance of saving souls. 'Money is power' and it can solve all the problems. Shaw proclaims that idealism depends on the needs. For instance, Barbara and Stephen ${ }^{7}$ are not in need of money, hence, they behave idealistically. The acts of Mrs. Baines, Lady Britomart ${ }^{8}$, Cusins ${ }^{9}$ and Undershaft demonstrate their realistic nature. The realists, as they appear in the play, are added with responsibilities while the idealists are carefree. Responsibility enjoins one to think realistically. Stephen and Barbara are idealists since they do not face any difficulty in earning their living. They do not have any responsibility on their shoulders. Stephen 'would die sooner than ask [his father] for another penny' (Shaw, 1965a, p. 464). Ironically, he takes his money from his mother who begs money from his father. He is not in need of it! But the people in need, shoulder a heavy responsibility that forces them to think realistically for continuance of their normal life.

The conflicting parts, however, are obdurate and contradict themselves. Barbara refuses to be bought by what she calls the sinners and challenges to save their souls instead. She refuses to receive both a sovereign offered by Bill as a charge for his defiance and the $£ 5,000$ offered by Undershaft. She calls both money as "conscience" and "tainted" respectively. Yet, she admits the necessity of the money '...Have we got money enough to keep the shelter open' (Shaw, 1965a, p. 483)? Without asking about money provenance, Barbara is happy and cheerful for getting donation from Lord Saxmundham. Amazingly, her happiness precedes her interrogation.

MRS BAINES. ... Lord Saxmundham has promised us five thousand pounds-

BARBARA. Hooray (Shaw, 1965a, p. 483)!

As a precautious step, Mrs. Baines accepts money from Undershaft and Bodger the cannons maker and whisky distiller respectively. She thinks offering money is an act of repentance. Whence, she pleads for both of the donators and donation. She insists on its necessity since the safety and continuance of the Army fall upon her as a commissioner. When the idealist and the realist are unable to accept tolerance, the turning point follows. Barbara rejects money and decides to leave the shelter and the Salvation Army as being corrupted.

Undershaft's ammunitions are not only the explosives but also his intellect to fight Barbara. He uses his experience to defeat his antagonists. Spiritual rituals are means by which Barbara converts and saves others' souls. Her duty calls for mercy and justice whereas Undershaft's for explosions and bombs. The two in conflict persons try to achieve their aims by all means. Barbara has religion to save souls while Undershaft has gunpowder to save money. The conflict between Barbara and Undershaft is between soul and body. Accordingly, the relation between money and religion is that between physical and spiritual. They complete each other. Physical stuff gained by money, feeds body whereas spiritual rituals feed soul. Those who try to save souls without money cannot attain their targets. A person, in order to save the soul, should have money in one hand and rituals in the other. To fulfil aims, there should be compatibility between body and soul as money feeds body and religion can feed souls. Undershaft says "...It is cheap work converting starving men with a Bible in one hand and a slice of bread in the other... Try your hand on my men: their souls are hungry because their bodies are full" (Shaw, 1965a, p. 499).

\section{A Bargain of Two Rounds}

The play is composed of three acts. The first act shows the introductory scene of the bargain while the other two reveal the two rounds bargain. Major Barbara is in bargaining play. The whole plot exposes a bargain of convert where announced in the first act of the play. The first round takes place in West Hamm Shelter where Barbara works. The second one takes place at Perivale St. Andrews where Undershaft's ammunitions headquarter is situated. Although Barbara loses the two rounds and in partially converted, she still has a hope for triumph. She seemingly makes tactics for continuing her challenge until victory. She tries to save her father's soul and helps him to get rid of gunpowder and ammunitions curse. Undershaft is still wayward and proud of his capitalism and belief. He mixes his job with religion and declares his secularism '... I am a Millionaire. That is my religion' (Shaw, 1965a, p. 476). 'His motto: Unashamed everybody knew' (Shaw, 1965a, p. 462). He is a capitalist descending from a state of foundling and lived a very miserable life during his childhood. Undershaft is so rude that he attacks religion and the Salvation Army; he defends the crime by calling poverty as the worst of crimes and 'the other crimes', however, 'have virtues beside it' (Shaw, 1965a, p. 498). He has his own understanding of 
sins as he mentions seven deadly $\operatorname{sins}^{10}$. He claims to have saved his daughter, Barbara, to enable her to live her life proudly. Without his money, which has saved her soul from the seven deadly sins, Barbara may have remained as one of the inhabitants of her shelter.

Shaw attacks the capitalists as being busy collecting money of poor people. He considers their misusage is a reaction and revenge to their saturnine past. The poor are completely scornful and are neglected by the capitalists. Thus, Undershaft scornfully helps the Salvation Army. His money is not as charity for the continuance of the Army but as business strategy to help increasing money and continuance of explosions. As the competitors still believing in the gravity of their opinion and doctrine, the encounters expect to increase. Let me say, it is true that every human needs food, clothes, fire, rent and taxes. Out of the seven deadly sins those Undershaft 'counts on his finger', he succeeds to fulfill only six. He is irresponsible about his family and unaware of paternity thus the last one he does not achieve. Accordingly, when he comes back to see his family, hardly could he recognize any.

Shaw pleads for the poor he himself experienced starvation in the early period of his life. His defense of poverty is clear even in his speech to his friends. "When the portly Alfred Hitchcock remarked, 'One look at you, Mr. Shaw, and I know there's famine in the land,' the lean and unflappable Shaw retorted, 'One look at you, Mr. Hitchcock, and I know who caused it'(qtd. in Peters, 1987, p. 149). He believes in the necessity of money. In other words, Shaw's idea is: instead of worrying for all the time for saving souls, one should think of saving money. There is no question, saving soul of the illicit and foundling is a way of purifying them from the curse of excessive desire for money. They may be conscious to their blind and bloody way of snapping the others' money. It can help make them lose their grip on the governmental and religious establishments. By this means, they may stop killing or support killers of innocents. This may materialize through the stable and intelligent manner. For instance, it is very difficult to force Undershaft to convert as a preacher or Salvationist as collects huge piles of money. Despite all of his money, Undershaft does not support his family. The interrogation is where his money goes. He is busy collecting money by selling gunpowder and cannons but his family is supported by their grandfather, the Earl of Steven. The Earl asks with surprise:

LADY BRITOMART. ...He says, [Earl of Stevenage] naturally enough that it is absurd that he should be asked to provide for the children of a man who is rolling in money (Shaw, 1965a, p. 462)

This shows his unawareness about paternity and neglect of family. On the contrary, he pretends he supports the Salvation Army. Udershaft looks like a man who plays a double game. By praising and mixing money with gunpowder, he gives an impression of the necessity for completing each other. Hence, he threatens the continuance of the idealistic establishments. Shaw exposes the source of the collected money by the gunpowder endorsing traders and then lines it to religion. Shaw is realistic in endorsing Undershaft's direct and candid declaration of the two main components of his religion, money and gunpowder.

CUSINS. Excuse me: is there any place in your religion for honor, justice, truth, love, mercy and so forth?

UNDERSHAFT. Yes: they are the graces and luxuries of a rich, strong, and safe life.

CUSINS. Suppose one is forced to choose between them and money or gunpowder?

UNDERSHAFT. Choose money and gunpowder; for without enough of both you cannot afford the others.

CUSINS. That is your religion?

UNDERSHAFT. Yes (Shaw, 1965a, p. 478).

Undershaft's dialogue reveals the future expectations and relationship between religion and munitions. Money alone is not enough to make the Salvation Army successful. It needs gunpowder as well. It is a future consideration that to help continuance of the religious establishments, there should be combination of money and munitions. Shaw foresees that the religious places are going to possess and make money to pay to the supporters of the establishment.

UNDERSHAFT. ....there are two things necessary to Salvation.

CUSINS. [disappointed, but polite] Ah, the Church Catechism. Charles Lomax also belongs to the Established Church.

UNDERSHAFT. The two things are-

CUSINS. Baptism and-

UNDERSHAFT. No. Money and gunpowder (Shaw, 1965a, p. 478).

Undershaft's intention to destroy the establishment is disclosed when he tempts them with money. Since he has thrown challenge to Barbara, he can seize any chance to get the bargain in his favour. He threatens not only 
Barbra, but also the existence of the Salvation Army. With his money, Undershaft aims at buying the establishment that embosoms Barbara.

CUSINS. Well, I can only say that if you think you will get her away from the Salvation Army by talking to her as you have been talking to me, you don't know Barbara.

UNDERSHAFT. My friend: I never ask for what I can buy.

CUSINS. [in a white fury] Do I understand you to imply that you can buy Barbara?

UNDERSHAFT. No; but I can buy the Salvation Army (Shaw, 1965a, p. 480).

The bargain for converting starts when they obviously declare their aims. The challenge is either to bring the workmen of the munitions factory to the shelters to save their souls or to transfer the poor of the shelters to the factory to let them save money. It is not possible that Barbara completely leaves her job as a saviour and starts working in the cannons factory to save more money. Or Undershaft should leave the huge and clean factory and sits in the shelters among the poor people preaching to save their souls. Socials and antisocial or in other words capitalist and anti capitalist are contradictory parts. It is clear that neither Barbara nor Undershaft can convert but each try to prove one belief is right and other is wrong.

Barbara is very optimistic and her confidence regarding her triumph over her father's soul, made her 'Tragic Optimist'. Barbara and her father are playing 'hide and seek' in their game of convert. It is a bargain of philosophy. The experienced person who has the ability to speak with rhetoric may defeat the other. It is the bargain of Shaw and his beliefs. Shaw believes that it is natural; the two are struggling to win. It is as Charles Darwin's the origin of Species - struggle for existence "11. Shaw elaborates:

"Each of us has not only the bird and fish in him, but also - and how much more strongly! - the savage, the barbarian, the hunter and the slayer, the warrior, the murderer, the thief, the coward, and the fanatic" (qtd. in Laurence, 1961, p. 18).

Undershaft plans to demonstrate his power over the Army to win Barbara. In this stage, the means of bargain is not munitions but religion and through it they intend to win the bargain. Undershaft points out that 'Religion is our business at present, because it is through religion alone that we can win Barbara' (Shaw, 1965a, p. 479). Barbara also expresses her intention to save her father's soul when she meets him. This is clear when her mother asks for none objecting of her father's visit, Barbara immediately replies: 'I! why should I? My father has a soul to be saved like anybody else. He's quite welcome as far as I am concerned' (Shaw, 1965a, p. 465). Moreover, Shaw prepares his struggling characters through their instinct and their previous knowledge of each other. When Undershaft meets his family members, after a long time of separation, he commits mistake in recognizing most of the attendants but Barbara. Shaw deliberately creates this situation to show his audience and readers the typicality of the conflicted parts.

UNDERSHAFT. Mr Cusins: I am much indebted to you for explaining so precisely. [Turning to Sarah] Barbara, my dear-

SARAH. [prompting him] Sarah.

UNDERSHAFT. Sarah, of course. [They shake hands. He goes over to Barbara]

Barbara-I am right this time, I hope.

BARBARA. Quite right. [They shake hands] (Shaw, 1965a, p. 467).

A very good example of the art of Shaw's technique is the illustration of the main plot in a short conversation. During their stay altogether at Mrs. Britomart house, after separation of a long period of time, Undershaft and Barbara start their bet. Undershaft proposes to visit Barbara's shelter and Barbara to visit his factory. Each tries to drag the other on to what he thinks the right track. The main bet is illustrated in short conversation:

UNDERSHAFT. May I ask have you ever saved a maker of cannons?

BARBARA. No. Will you let me try?

UNDERSHAFT. Well, I will make a bargain with you. If I go to see you tomorrow in your Salvation Shelter, will you come the day after to see me in my cannon works?

BARBARA. Take care. It may end in your giving up the cannons for the sake of the Salvation Army.

UNDERSHAFT. Are you sure it will not end in your giving up the Salvation Army for the sake of the cannons?

BARBARA. I will take my chance of that. 
UNDERSHAFT. And I will take my chance of the other. [They shake hands on it].... (Shaw, 1965a, p. 469).

Shaw dramatically prepares us for the challenge through the rivals' pre-knowledge of each other. Undershaft admires Barbara at the first look and becomes eager to know something about her work and religion. For that reason they start the bargain. The first round takes place in the West Hamm Shelter. When Undershaft arrives at the shelter, Barbara is occupied with saving Bill's soul. He curiously sits to watch his daughter's work. Barbara continues her campaign for saving Bill's soul. Just as Bill is about to break down a drum is heard in the shelter and Cusins enters. Bill is horrified and rushes out of the shelter to Canning town. The appearance of Cusins and the sound of the drum are a signal to wake Barbara up and the person whom she tries to save. Shaw intends to say that converted people are magnetically affected. In this scene, Shaw's aesthetic aspect is revealed. Unfortunately, Barbra loses the first attempt at her shelter. The other disappointing attempt, however, is the decision to accept the donation by Mrs. Baines. Moreover, Barbara is shocked to see her fiancé cheering her rival in her presence. Through his cheers, Cusins gives Barbara a buffet. Gradually, the feathers of Barbara's wings are extracted by her father. The first round is scored to Undershaft and Barbara is left in her shaken faith and distress.

The next day, as the next round of bargain, the family is preparing to visit the cannons factory. Barbara is looking like shattered and frustrated as she has taken her Army uniform off. In Perivale St Andrews, Barbra is shocked to see the clean and beautiful place of her father. In the ammunitions factory, the group's main matter of discussion is the next inherent of the factory. Stephen, as the expected inherent, is not ready to be a foundling ${ }^{12}$. The unexpected attack to Barbara, this time, comes from Cusins - her fiancé who confesses that in England, his parents are outcasts as their marriage is legal in Australia. His mother is his father's deceased wife's sister; and in England he is consequently a foundling (Shaw, 1965a, p. 495). His greed for inheriting the munitions factory has made him blind. Honour, seemingly, as compared to money is nonsense. A foundling, as compared to a homeless poor man, is a better position. By her fiancé's confession, Barbara loses the last hope of victory. Undershaft feels triumphant over Barbara. He urges Barbara to think realistically as the future lies behind machinery and ammunitions. He advises her to take the clothes of the religion and morality off. She is a young girl and their dresses are old fashioned and no longer fit to her. Barbara is fit to be in a prosperous and richly decorated office than to be in a slum or dark shelter. It is better to treat the germs of poverty by killing than living among them. She has to think realistically and to give poor people food and clothes to protect them from hunger and cold than to draw their attention to philosophy of imagination. They cannot understand such philosophy of hunger. It makes them listen abstractedly and thinking of their meals when their stomach is crying. Such an intellectual preacher like Undershaft is really able to affect others. He, finally, has the ability to convert both of Barbara and her fiancé. Just when Barbara and her fiancé are left alone, the fatal blow takes place. Barbara admits to being defeated, but has not regretted, by proclaiming that up until yesterday she believed herself in the power of God, but when her father came, he showed her that she was in the power of Bodger and Undershaft (Shaw, 1965, p. 497). Cusins courageously collects his powers and decides to enlighten his dark future. When Cusins feels the weighing of power, he immediately throws himself to the hands of ammunitions and explosives. He gives away his soul to his new foundling father-in-law in consideration of new luxury life of disrepute. Finally, Barbara is left alone sticking to her morals and beliefs. She cannot stand the case and "she runs to the shed, and calls, childlike Mamma! Mamma! ... I want Mamma"

LADY BRITOMART. ....What do you want, Barbara?

BARBARA. I want a house in the village to live in with Dolly. [Dragging at the skirt] Come and tell me which one to take (Shaw, 1965a, p. 503).

\section{Conclusion}

In this play, the first ethical aim is to overcome one's greed and ego. The monetary support that is given, whether considered a charity or bribery, helps to disperse Barbara and the Salvation Army as well. It confuses the Army since Barbra herself calls it as 'tainted'. This accusation reduces confidence in the Army as Mrs. Baines is compelled to accept it. Barbara is also confused for foolishly leaving the Army to wolves to snap. She gives a good chance to her rivals to take advantage of this. Barbara embarrasses herself when she refuses the donated money. To satisfy ego, she pretends to make a new tactic for saving souls of workers at the ammunitions manufacture. She should have painted money with colour of charity instead of bribery. The second ethical aim is to overcome the indifference to other's feelings and its negative effect. The conflict inside the chief members of the Salvation Army is a good example. Such a fault supports Undershaft makes him feel triumphant and justify his intervention.

Barbara ridiculously rejects Undershaft's money while she grows up by his beneficence. Barbara's self 
-contradiction makes Undershaft challenge and force her to lose more than expected. Mrs. Baines is affronted and 'with tears in her eyes' asks Barbara; 'do you think I am wrong to take the money' (Shaw, 1965a, p. 485)? Barbara loses but still ruminates in an attempt seemingly to save her grandeur.

In case of emergency, money is superior to dignity. Mrs. Baines and Lady Britomart are aware of this. Lady Britomart proclaims: "I must put my pride in my pocket and ask for it [money]" (Shaw, 1965a, p. 464)! Mrs. Baines also professedly accepts the donation. If Barbara were in Mrs. Baines shoes, she would naturally accept the money. If Stephen were in his mother's shoes, he would also behave the same way. Shaw declares unexpected result by making both of Barbara and her fiancé shift from the shelter to the factory. Cusins voluntarily shifts while Barbra is compelled. Barbara converts into a realist illicit munitions magnate's daughter and a fiancé of an illicit inheritor. Accordingly, they live in arms manufacture as well. Barbara is easily disappointed and surrendered. She deserts her religious rights and delivers the Salvation Army to her concurrent. She is disavowed says: 'I can't pray now. Perhaps I shall never pray again'. She takes off the silver 'S' brooch from her collar and pins it on her father's and steps back towards the table, showing him to the others (Shaw, 1965a, p. 464).

\section{References}

Fink, Joel G. (2011). Major Barbara, and: The Circle (review). Theatre Journal, 63(2), 272-276. http://dx.doi.org/10.1353/tj.2011.0055

Fiske, Irving. (1974). Bernard Shaw's Debt to William Blake. London: Folcroft Library Editions.

Hartnoll, Phyllis. (1975). Who's Who in Shaw. London: Elm Tree Books.

Laurence, Dan H. (Ed.). (1961). Platform and Pulpit. New York, NY: HILL \& Wag.

Lombardi, Esther. (2012). Medieval Period: Where did it all begin? Retrieved from $\mathrm{http}: / /$ classiclit.about.com/od/medievalmiddleenglish/a/aa_medieval.htm

Morgan, Margery M. (1972). The Shavian Playground: An Exploration of the Art of George Bernard Shaw. London: Methuen \& Co. Ltd.

Peters, Sally. (1996). Bernard Shaw: The Ascent of the Superman. New Haven and London: Yale University Press.

Shaw, George Bernard. (1965a). The Complete Plays of Bernard Shaw. London: Paul Hamlyn.

Shaw, George Bernard. (1965b). The Complete Prefaces of Bernard Shaw. London: Paul Hamlyn.

Teachout, Terry. (2010). When Hellman's Foxes Were Kits. The Wall Street Journal/ theatre. Retrieved from http://online.wsj.com/article/SB10001424052748703632304575451742111744232.html

Wikipedia the free encyclopedia. Retrieved from http://en.wikipedia.org/wiki/The_Salvation_Army and http://en.wikipedia.org/wiki/On_the_Origin_of_Species

Williams, Nicholas. (2006). Shaw Reinterpreted. SHAW The Annual of Bernard Shaw Studies, 26, 143-161. http://dx.doi.org/10.1353/shaw.2006.0022

\section{Author}

Azeez Jasim Mohammed is currently a Doctoral Student of English Literature at Department of English, Faculty of Arts, Banaras Hindu University (BHU) - India. He has been a Visiting Doctoral Student at Department of English, WWU - Muenster, Germany for the period $16^{\text {th }}$ July $-3^{\text {rd }}$ October, 2012.

\section{Acknowledgement}

The author is indebted to Prof. Dr. Guru Charan Behera, Professor of English (Contemporary Literature) at Department of English - B.H.U. He is also very grateful to Prof. Dr. Klaus Stierstorfer, Chair of British Studies, Department of English, WWU - Muenster, Germany for the good chance of visiting University of Muenster and all the facilities. He finally submits especial thanks to the officers at the University of Muenster for kind help.

\section{Notes}

${ }^{1}$ The Salvation Army is an international movement known for its thrift stores and charity work that operates in over 120 countries. It was founded in 1865 in the United Kingdom by William Booth and his wife Catherine as the north London Christian Mission and with a quasi-military structure. (Wikipedia, the free encyclopedia).

${ }^{2}$ Bill Walker: A rough customer who comes to the West Ham Salvation Army shelter in search of his girl Mog 
Habbijam, who has been converted by Jenny Hill (Hartnoll, 1975, p. 219)

${ }^{3}$ Jenny Hill: An eighteen years old Salvation Army lass, pretty, pale, overwrought. She brings the unemployed Peter Shirley to the West Ham shelter for meal, and is knocked down by brutal Bill Walker when he comes looking for his girl, whom Jenny has converted. (Hartnoll, 1975, p. 112)

${ }^{4}$ Barbara Undershaft: the daughter of Lady Britomart, robust, jolly, and energetic. Bored with a rich, idle life, paid for by her father Andrew, who is separated from his wife, she has joined the Salvation Army, as has her fiancé Adolphus Cusins. (Hartnoll, 1975, p. 213)

${ }^{5}$ Andrew Undershaft: A wealthy industrialist (known to his workmen as Dandy Andy). He is the head of a vast armaments factory, which since its foundation has been handed down from one adopted foundling founder, each being named Andrew Undershaft. (Hartnoll, 1975, p. 213)

${ }^{6}$ Mrs. Baines: A commissioner in the Salvation Army; 'a woman of about forty, with caressing, urgent voice and an appealing manner'. (Hartnoll, 1975, p. 11)

${ }^{7}$ Stephen Undershaft: The only son of Lady Britomart and her industrialist husband Andrew. He cannot inherit his father's immense armaments factory, as by tradition it must go to an adopted foundling. (Hartnoll, 1975, p. 215).

${ }^{8}$ Lady Britomart: the daughter of the Earl of Stevenson, and wife of the armaments millionaire Andrew Undershaft, .... She left him after the birth of their son because he refused to break the tradition by which the firm had always been left to an adopted foundling, but now that her two daughters need dowries, she sends for him to discuss the matter. (Hartnoll, 1975, p. 214)

${ }^{9}$ Adolphus Cusins: A young Australian, a professor of Greek, who is engaged to Barbara Undershaft. For love of her he has joined the Salvation Army... (Hartnoll, 1975, p. 63)

${ }^{10}$ Undershaft's seven deadly sins are: Food, clothing, firing, rent, taxes, respectability and children (Shaw, 1965a, p. 498).

${ }^{11}$ On the Origin of Species, published on 24 November 1859, is a work of scientific literature by Charles Darwin which is considered to be the foundation of evolutionary biology. Its full title was On the Origin of Species by Means of Natural Selection, or the Preservation of Favoured Races in the Struggle for Life. (Wikipedia, the free encyclopedia).

${ }^{12}$ Lady Britomart explains to Stephen the fact of the foundling: "The Undershafts are descended from a foundling in the parish of St Andrew Undershaft in the city. That was long ago, in the reign of James the First. Well, this foundling was adopted by an armorer and gun-maker. In the course of time the foundling succeeded to the business; and from some notion of gratitude, or some vow or something, he adopted another foundling, and left the business to him. And that foundling did the same. Ever since that, the cannon business has always been left to an adopted foundling named Andrew Undershaft" (Shaw, 1965a, p. 463). 